\title{
Evaluation of Large White Yorkshire Boar Semen Fractions
}

\author{
Malati Naik $^{1}$, Hiron M. Harshan ${ }^{1}$, K. Promod ${ }^{1}$, Leeba Chacko ${ }^{1}$, \\ A.P. Usha ${ }^{2}$, C. Sunanda ${ }^{3}$ and M.P. Unnikrishnan ${ }^{2}$ \\ ${ }^{1}$ Department of Veterinary and Animal Sciences, Pookode, Lakkidi P.O., \\ Wayanad, Kerala - 673 576, India \\ ${ }^{2}$ Department of Farms, KVASU and Professor and Head, Centre for Pig Production and \\ Research, Mannuthy, India \\ ${ }^{3}$ Department of Statistics, CVAS, Pookode, India \\ *Corresponding author
}

\section{A B S T R A C T}

Keywords

Boar semen, Sperm rich fraction, Gloved hand method

\section{Article Info}

Accepted:

12 October 2019

Available Online:

10 November 2019
Boar semen is ejaculated as three uneven fractions. Recent studies have reported that the spermatozoa in initial portion of sperm rich fraction (SRF) of the ejaculates are more resistant to cold shock and survive cryopreservation better than the spermatozoa in the rest of the ejaculate. The present work was carried out to assess the quality of Large white Yorkshire (LWY) boar semen fractions reared at Kerala. Semen collected with gloved-hand technique as fractions of $10 \mathrm{~mL}$ each (initial $10 \mathrm{~mL}$ of SRF - F1; rest of SRF - F2) were subjected to quality assessments of colour, volume, $\mathrm{pH}$, sperm concentration and sperm progressive motility. Upon statistical analysis, significant difference was noticed in volume of semen ejaculate between boars and in $\mathrm{pH}$ and sperm concentration between fractions of the ejaculate.

\section{Introduction}

Commercial pig farming is the one of the best and profitable business, can contribute national income to our country highly. This is especially true in Kerala scenario, where pig production has got acceptance and has gained popularity because of certain inherent traits of pigs like high fecundity, better-feed conversion efficiency, early maturity and short generation interval, relatively smaller capital investment that can contribute to faster economic return to the farmers.

Artificial insemination (AI) using cryopreserved semen has showed less fertility and it requires high sperm numbers for optimum fertility. Boar sperm is highly 
sensitive to low temperature as its plasma membrane contains high levels of unsaturated phospholipids and low cholesterol, which makes the boar sperm highly sensitive to low temperature. The higher sensitivity has led to the use of boar semen preserved at $15^{\circ} \mathrm{C}$ for routine insemination rather than cryopreserved semen as in other domestic species. Boar ejaculates semen in three uneven fractions as in dog and stallion, which are expelled as jets or spurts. Few studies have reported that the initial $10 \mathrm{~mL}$ of sperm rich fraction (SRF) was resilient to cooling, freezing and thawing because of its lower bicarbonate level and presence or absence of specific proteins. Hence a study was framed to assess quality of boar semen fractions (F1 and F2).

\section{Materials and Methods}

Fifty five boar semen ejaculates were collected using gloved hand technique from four LWY boars maintained at the Centre for pig production and research, Mannuthy. Ejaculates were collected as fractions of 10 $\mathrm{mL}$ each in sterile $15 \mathrm{~mL}$ centrifuge tubes, allowing it to pass through a Buchner funnel to separate gel mass. The initial $10 \mathrm{~mL}$ of sperm rich fraction was considered as F1 and the remaining sperm rich fraction as F2 for the further study. The collected semen fractions were immediately transferred to an insulated container and transported to the laboratory for preliminary evaluation. Semen was collected from the boars once per day at a frequency of twice a week with an interval of three to four days between collections from the same boar.

The fresh semen collected was evaluated for volume, colour, $\mathrm{pH}$, sperm progressive motility and concentration. The volume of semen ejaculate as fractions was assessed by using graduated test tubes. The colour of F1 and $\mathrm{F} 2$ of the ejaculate was visually assessed separately and graded as watery, milky or thick milky based on the intensity of the white colour of the fractions when taken in the graduated test tubes. The $\mathrm{pH}$ of the fractions was assessed by taking a drop of the semen to the designated well of a hand held $\mathrm{pH}$ meter (Horiba, Model - LAQUA twin pH-11, USA) after calibrating the equipment with a $\mathrm{pH} 7.0$ buffer. The equipment measured $\mathrm{pH}$ to an accuracy of one decimal point. The sperm progressive motility in the F1 and F2 fraction was assessed after mixing $10 \mu \mathrm{L}$ of neat semen with $100 \mu \mathrm{L}$ of PBS. Twenty five microlitre of diluted semen was taken on a clean, grease free glass slide, covered with a clean cover slip and examined under 400x magnification of a phase contrast microscope (Olympus, Model: Magnus MLX, India) with bio-therm stage facility maintained at $37^{\circ} \mathrm{C}$. Semen samples with a minimum of 70 per cent sperm progressive motility were selected for the study. The sperm concentration of each fractions of boar semen ejaculate was determined by using a Neubaeur counting chamber after diluting the semen to 1:200 using eosin-formal-saline (Salisbury et al., 1985). The sperm concentration was expressed in millions $/ \mathrm{mL}$.

\section{Results and Discussion}

Among all the collections of phase I and II (n = 30), the volume of semen in LWY boar ejaculates ranged between 103.5-220.5 mL, with a mean volume of $144.9 \pm 5.29 \mathrm{~mL}$. Individual boar semen volume ranged from $108.5 \pm 1.60$ to $176.25 \pm 9.16 \mathrm{~mL}$. The volume of semen differed $(\mathrm{p}<0.01)$ significantly between boar 1, 2 and 4; while boar 3 had a similar ejaculate volume as boar 1. Kantharaj (2001) reported mean ejaculate semen volume of $209.50 \pm 4.63 \mathrm{~mL}$ in LWY boar. It could vary from $50-400 \mathrm{~mL}$ and 125 $500 \mathrm{~mL}$ as reported by Hafez (1993) and Arthur et al., (1996), respectively. Wilson (2018) recorded the mean total ejaculate volume of $167.73 \pm 7.95 \mathrm{~mL}$ in LWY boar. The differences in semen volume reported by 
the other workers might be attributed to differences in the method of collection, frequency of collection, season of collection, age and size of the boars and other environmental association including feeding and managerial practices responsible for modifying the semen ejaculation.

Out of 55 ejaculates collected, 42 of F1 were thick milky and 13 were milky, while 42 of F2 were milky and 13 thin milky in colour. The colour in the rest of the ejaculate fractions varied from thin milky to watery. Studies of Hancock (1959) observed amorphous watery jelly-like mass in first 10-20 mL (pre sperm) followed by around $40 \mathrm{~mL}$ of sperm containing fraction which was densely opaque and similar to bull semen. Succeeding fractions became progressively less opaque due to progressive reduction of sperm concentration. They noted that decrease in sperm concentration would increase the transparency of the semen ejaculate.

The overall mean $\mathrm{pH}$ of fresh semen fractions (F1 and F2) was found to be on the alkaline side $(7.36 \pm 0.01 ; 7.45 \pm 0.01)$ ranging from 7.3-7.5 and 7.4-7.5, respectively. On an individual boar basis the $\mathrm{pH}$ of $\mathrm{F} 1$ and $\mathrm{F} 2$ was found to range from $7.35 \pm 0.02$ to $7.37 \pm 0.02$ and $7.40 \pm 0.00$ to $7.47 \pm 0.08$, respectively. Although there was no significant difference between boars, the $\mathrm{pH}$ of semen ejaculate differed significantly between fractions $(\mathrm{p}<$ 0.01) with those in F1 being lower. Roberts (1986) reported the normal $\mathrm{pH}$ of boar semen ranged from 7.0 to 7.8 (alkaline side). The alkalinity or acidity of the semen was affected by the higher or lower levels of accessory gland secretions in the ejaculate. Higher the accessory gland secretions to the ejaculate, higher would be the alkalinity of semen (Mann, 1974). The recorded $\mathrm{pH}$ values were similar to reports of Aamdal and Hogset (1957) where the $\mathrm{pH}$ value of boar semen varied from 7.43 to 7.5 in pre-sperm and sperm rich fractions and from 7.43 to 7.5 in post spermatic fractions. Saraviaet al., (2010) reported lower $\mathrm{pH}(7.07 \pm 0.03)$ with lower amount of bicarbonate $(13.71 \pm 0.64 \mathrm{mM} / \mathrm{L})$ in first $10 \mathrm{~mL}$ of SRF (F1) than the rest of $\mathrm{SRF}$ (F2). F2 had $\mathrm{pH}$ of $7.32 \pm 0.07$ with significantly higher bicarbonate level (20.21 \pm $0.79 \mathrm{mM} / \mathrm{L}$ ) than $\mathrm{F} 1$. In the present study, it was noted that the $\mathrm{pH}$ of boar semen varies in the different fractions of the same ejaculate and variation was also observed from one ejaculate to another. Specifically in $\mathrm{F} 1$, the $\mathrm{pH}$ was found to be lower compared to F2, which might be due to low bicarbonate level in the F1 and also higher sperm concentration credited to higher metabolic end products consecutively higher lactic acid production.

The overall mean sperm progressive motility in both F1 and F2 fractions, immediately after collection was $84.06 \pm 0.93$ and $82.5 \pm 1.02$ per cent, respectively, with a range of 75-90 in both the fractions. In individual boars, sperm progressive motility in $\mathrm{F} 1$ varied from $81.25 \pm$ 2.39 to $86.25 \pm 1.25$ per cent and in $\mathrm{F} 2$ it varied from $80.00 \pm 2.04$ to $83.75 \pm 2.39$ per cent. No significant variation was observed in sperm progressive motility between boars, or between fractions. Pena et al., (2003b) reported more linear pattern of motility in the first $10 \mathrm{~mL}$ SRF than rest of ejaculate, this difference might be due to differences in bicarbonate levels or protein components of seminal plasma in two portions. In present study, no difference in progressive motility was observed between fractions, which might be due to the very short exposure of sperm to the seminal plasma before they were evaluated for motility.

The overall mean \pm SE sperm concentration in F1 was found to be $873.12 \pm 91.34$ million $/ \mathrm{mL}$ with a range of 450.00-1570.00 million $/ \mathrm{mL}$ and F2 had sperm concentration of $460.00 \pm$ 35.24 million $/ \mathrm{mL}$ with range of $240-690$ million/mL (Table 1 and 2). 
Table.1 Total ejaculate volume in large white Yorkshire boars (Range, Mean \pm SE)

\begin{tabular}{|c|c|c|c|}
\hline & $\begin{array}{c}\text { Mean } \pm \mathbf{S E} \\
(\text { Range })\end{array}$ & $\begin{array}{c}\text { Overall range and } \\
\text { Mean } \pm \mathbf{S E}(\mathbf{n}=\mathbf{3 0})\end{array}$ & F-value (p-value) \\
\hline Boar 1 (n=8) & $150.06 \pm 5.56^{\mathrm{B}}$ & $144.90 \pm 5.291$ & $22.339(0.01)^{* *}$ \\
& $(125-167)$ & $(103.5-220.5)$ & \\
\hline Boar 2 (n=8) & $176.25 \pm 9.16^{\mathrm{A}}$ & & \\
& $(150.5-220.5)$ & & \\
\hline Boar 3 (n=7) & $139.57 \pm 2.46^{\mathrm{B}}$ & & \\
& $(129.5-149)$ & & \\
\hline Boar 4 (n=7) & $108.50 \pm 1.60^{\mathrm{C}}$ & & \\
& $(103.5-116)$ & & \\
\hline
\end{tabular}

** Significant at 0.01 level; Means having capital letter as superscript differs significantly within a column.

Table.2 The fresh semen characteristics of large white Yorkshire boar ejaculates in F1 and F2

\begin{tabular}{|c|c|c|c|c|}
\hline \multirow[t]{2}{*}{ Semen characteristics } & \multirow[t]{2}{*}{ Animal } & \multicolumn{2}{|c|}{ Mean \pm SE (range) } & \multirow{2}{*}{\begin{tabular}{|l}
$\begin{array}{l}\text { F-value } \\
\text { (p-value) }\end{array}$ \\
Between \\
fractions
\end{tabular}} \\
\hline & & $\mathrm{F} 1$ & $\mathrm{~F} 2$ & \\
\hline \multirow[t]{5}{*}{ pH } & $\begin{array}{c}\text { Boar 1 } \\
(n=4)\end{array}$ & $\begin{array}{c}7.35 \pm 0.02 \\
(7.3-7.4)\end{array}$ & $\begin{array}{c}7.47 \pm 0.02 \\
(7.4-7.5)\end{array}$ & \multirow[t]{5}{*}{$45(0.01)^{* *}$} \\
\hline & $\begin{array}{c}\text { Boar } 2 \\
(\mathrm{n}=4)\end{array}$ & $\begin{array}{c}7.37 \pm 0.02 \\
(7.3-7.4)\end{array}$ & $\begin{array}{l}7.47 \pm 0.08 \\
(7.4-7.5)\end{array}$ & \\
\hline & $\begin{array}{l}\text { Boar } 3 \\
(\mathrm{n}=4)\end{array}$ & $\begin{array}{c}7.35 \pm 0.05 \\
(7.3-7.5)\end{array}$ & $\begin{array}{c}7.4 \pm 0.00 \\
(7.4)\end{array}$ & \\
\hline & $\begin{array}{c}\text { Boar } 4 \\
(n=4)\end{array}$ & $\begin{array}{c}7.37 \pm 0.02 \\
(7.3-7.4)\end{array}$ & $\begin{array}{c}7.47 \pm 0.02 \\
(7.4-7.5)\end{array}$ & \\
\hline & $\begin{array}{c}\text { Overall } \\
\text { Mean } \pm \text { SE } \\
\text { (range) } \\
n=30\end{array}$ & $\begin{array}{c}7.36 \pm 0.01 \\
(7.3-7.5)\end{array}$ & $\begin{array}{l}7.45 \pm 0.01 \\
(7.4-7.5)\end{array}$ & \\
\hline \multirow[t]{5}{*}{$\begin{array}{l}\text { Progressive motility } \\
\text { (in per cent) }\end{array}$} & $\begin{array}{c}\text { Boar } 1 \\
(n=4)\end{array}$ & $\begin{array}{c}81.25 \pm 2.39 \\
(75-85)\end{array}$ & $\begin{array}{c}80.00 \pm 2.04 \\
(75-85)\end{array}$ & \multirow[t]{5}{*}{$1.27(0.27)^{\mathrm{ns}}$} \\
\hline & $\begin{array}{l}\text { Boar } 2 \\
(n=4)\end{array}$ & $\begin{array}{c}86.25 \pm 1.25 \\
(85-90)\end{array}$ & $\begin{array}{c}82.50 \pm 3.22 \\
(75-90)\end{array}$ & \\
\hline & $\begin{array}{l}\text { Boar } 3 \\
(n=4)\end{array}$ & $\begin{array}{l}85.00 \pm 2.04 \\
\quad(80-90)\end{array}$ & $\begin{array}{c}83.75 \pm 2.39 \\
(80-90)\end{array}$ & \\
\hline & $\begin{array}{c}\text { Boar } 4 \\
(n=4)\end{array}$ & $\begin{array}{c}83.75 \pm 1.25 \\
(80-85)\end{array}$ & $\begin{array}{c}81.25 \pm 1.25 \\
(80-85)\end{array}$ & \\
\hline & $\begin{array}{c}\text { Overall } \\
\text { Mean } \pm \text { SE } \\
\text { (range) } \\
n=30\end{array}$ & $\begin{array}{l}84.06 \pm 0.93 \\
(75-90)\end{array}$ & $\begin{array}{l}82.5 \pm 1.02 \\
\quad(75-90)\end{array}$ & \\
\hline Sperm concentration & Boar 1 & $875.00 \pm 13.22$ & $495.00 \pm 6.45$ & 226.65 \\
\hline
\end{tabular}




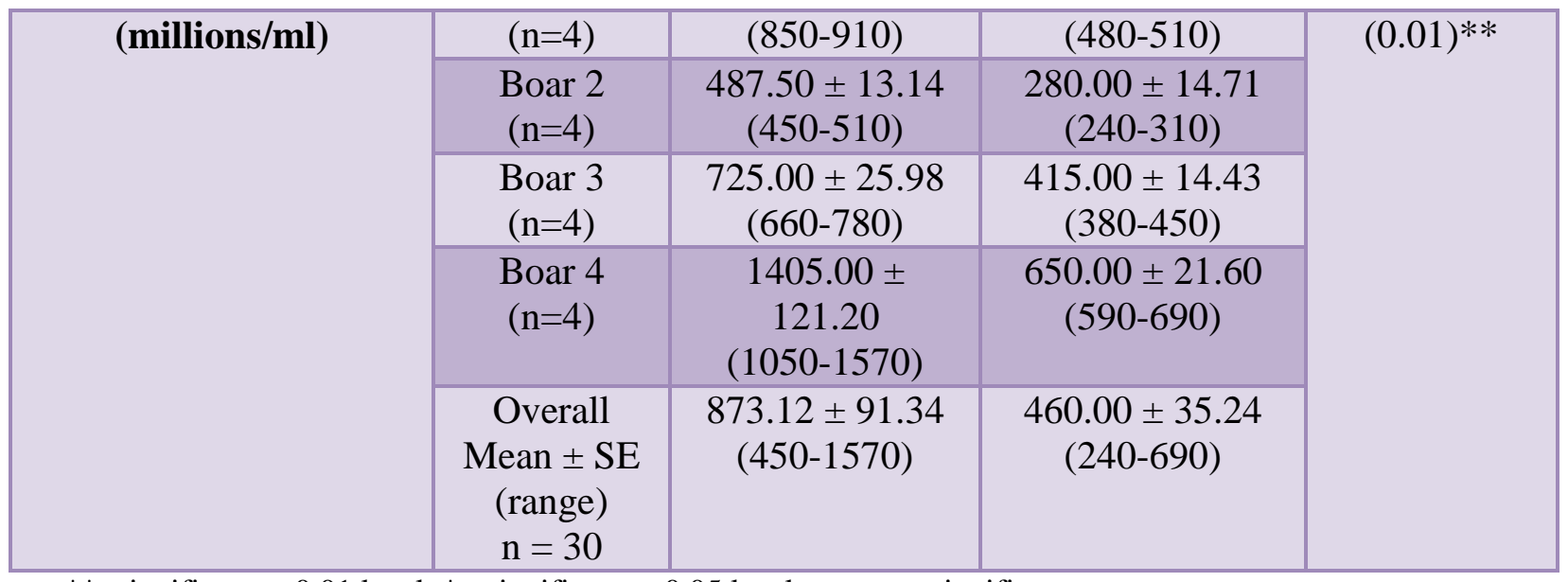

**- significant at 0.01 level; * - significant at 0.05 level; $\mathrm{ns}$ - non significant

On an individual boar basis, the $\mathrm{F} 1$ sperm concentration varied from $487.50 \pm 13.14$ to $1405.00 \pm 121.20$ million $/ \mathrm{mL}$ and sperm concentration in $\mathrm{F} 2$ varied from $280.00 \pm$ 14.71 to $650.00 \pm 21.60 \mathrm{million} / \mathrm{mL}$.

There was significant difference between boars $(\mathrm{p}<0.01)$ and between fractions $(\mathrm{p}<$ $0.01)$ in the sperm concentration of semen ejaculates. Similar findings were recorded by Siqueira et al., (2011), where researchers found higher sperm concentration in F1 (1860 $\left.\pm 0.20 \times 10^{6}\right)$ than F2 $\left(1250 \pm 0.14 \times 10^{6}\right)$.

Glover and Mann (1954) observed that the sperm concentration varied in different fractions and even in different waves of ejaculation. As the study has shown significant differences in the $\mathrm{pH}$ and sperm concentration between the two fractions F1 and F2, it might be postulated that there exists differences in the composition and properties of the semen of this fraction and hence the keeping quality of these fractions may differ.

\section{Acknowledgement}

The authors acknowledge the facilities and funding provided by the Head, department of Animal Reproduction, Gynaecology and Obstetrics, CVAS, Mannuthy, Dean, CVAS, Mannuthy and the DAR, KVASU.

\section{References}

Aamdal, J., and Hogest, I. 1957. Artificial insemination in swine. J.Amer. Vet. Med. Ass. 131: 59-64.

Arthur, G. H., Noakes, D. E., Pearson, H. and Parkinson, T. J. 1996. Veterinary Reproduction and Obstetrics. ( $7^{\text {th }}$ Ed.), W. B. Saunders Company, London, pp. 27- 28.

Glover, T. and Mann, T. 1954. On the composition of boar semen. The $J$. Agric. Sci. 44: 355-360.

Hafez, E.S.E. 1993. Reproduction in Farm Animals, 6th Edition, Ed. Lea \& Febiger, Philadelphia.

Hancock, 1. L. 1959. Semen and testis characteristics and sexual-behaviour of boars. J.Agric. Sci.53: 313.

Kantharaj, S. 2001. Evaluation of boar semen extended in Beltsville thaw solution. M. V. Sc thesis, Kerala Agricultural University, Mannuthy.

Mann, T. 1974. Secretory function of the prostate, seminal vesicle and other male accessory organs of reproduction. J. Reprod. Fert. 37: 179-188.

Pena, F. J., Johannisson, A., Wallgren, M. and Rodriguez Martinez, H. $2003 b$. Assessment of fresh and frozenthawed boar semen using an annexin-v assay: a new method to evaluate sperm 
membrane integrity. Theriogenology. 60: 677-89.

Roberts, S. J. 1986. Veterinary Obstetrics and Genital Diseases (Theriogenology). $3^{\text {rd }}$ ed., Edward Brothers, Inc. Ann Arbor, Minchigan. 872-893.

Saravia, F., Wallgren, M. and RodríguezMartínez, H. 2010. Freezing of boar semen can be simplified by handling a specific portion of the ejaculate with a shorter procedure and MiniFlatPack packaging. Anim. Reprod. Sci.117: 279-287.

Salisbury, G.W., Van Denmark, N. L. and Lodge, J. R. 1985. Physiology of reproduction and artificial insemination of cattle, 2nd edn, CBS Pub And Distributors, Shahdara, New
Delhi, India.

Siqueira, A.P., Wallgren, M., Hossain, M. S., Johannisson, A., Sanz, L., Calvete, J. J. and Rodriguez-Martinez, H. 2011. Quality of boar spermatozoa from the sperm-peak portion of the ejaculate after simplified freezing in MiniFlatpacks compared to the remaining spermatozoa of the spermrich fraction. Theriogenology, 75: 1175-1184.

Wilson, M. 2018. Freezability of boar semen supplemented with sodium dodecyl sulphate in low or high sperm concentration doses. M. V. Sc thesis. Kerala Agricultural University, Pookode.

\section{How to cite this article:}

Malati Naik, Hiron M. Harshan, K. Promod, Leeba Chacko, A.P. Usha, C. Sunanda and Unnikrishnan, M.P. 2019. Evaluation of Large White Yorkshire Boar Semen Fractions. Int.J.Curr.Microbiol.App.Sci. 8(11): 1645-1650. doi: https://doi.org/10.20546/ijcmas.2019.811.190 